\title{
Do the Caregivers Of Under-Fives Have Proper Health Care Seeking Behaviour for Their Children? A Study from Urban Slums of a City in Eastern India
}

\section{Parimala Mohanty ${ }^{1}$, Sudhir Kumar Satpathy ${ }^{2}$, Sibabratta Patnaik ${ }^{3}$ and Lipilekha Patnaik ${ }^{1}$}

${ }^{1}$ Department of Community Medicine, Institute of Medical Sciences and SUM Hospital, Siksha 'O' Anusandhan deemed to be University,Bhubaneswar, India

${ }^{2}$ School of Public Health, KIIT University, Bhubaneswar, India

${ }^{3}$ Department of Paediatrics, Kalinga Institute of Medical Science, KIIT University, Bhubaneswar, India

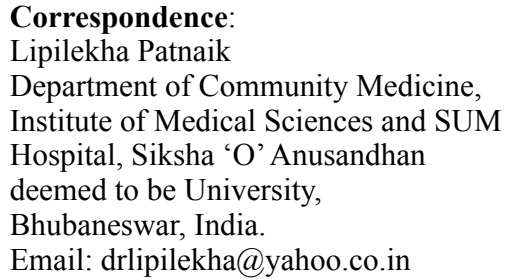

Department of Community Medicine, Institute of Medical Sciences and SUM Hospital, Siksha 'O' Anusandhan deemed to be University,

Bhubaneswar, India.

Email: drlipilekha@yahoo.co.in

DOI: $10.3126 /$ jnps.v41i2.31642

Submitted on: 2020-09-30

Accepted on: 2021-06-27

\section{Acknowledgements: None}

Funding: Nil

Conflict of Interest: None declared

Permission from IRB: Yes

To cite this article: Mohanty $\mathrm{P}$, Satpathy SK, Patnaik S. Do the Caregivers Of Under-Fives Have Proper Health Care Seeking Behaviour for Their Children? A Study from Urban Slums of a City in Eastern India. J Nepal Paediatr Soc. 2021;41(2):169-76.

\section{ABSTRACT}

Introduction: The morbidity and mortality among under-five children are many times higher in slums than more privileged urban neighbourhoods. This could be correlated with the caregivers' behaviour too. Therefore, we intended to assess the health care seeking behaviour for their children among caregivers of under-five children in urban slums of Bhubaneswar city.

Methods: It was a cross-sectional study conducted during Jan 2019 to April 2019 in Bhubaneswar, India. Data regarding health care seeking behaviour of 530 caregivers of under-five (U5) children residing in urban slums of Bhubaneswar, whose children suffered from any illness in last one month, were collected.

Results: The most common childhood illnesses for which healthcare were sought were diarrhoeal diseases $(30.4 \%)$ followed by respiratory infections $(29.1 \%)$. A concept analysis of the predisposing factors was built up as "socio cultural context", "economic context", "education context", and "individual preference" to know the health care seeking pattern. The health care seeking behaviour among the caregivers of under-five children was significantly associated with sex of child, size of the household, social group of caregiver, mother with mass media knowledge, age, education and occupation of mother, mother having BPL card, if suffering from chronic disease, decision making person for seeking health care, time lapse in approaching the health care facility and income loss due to U5 children illnesses.

Conclusions: The challenge is to know about signs and symptoms of ill-health and to recognise when to seek health care services. Measures can be taken to promote awareness for seeking timely appropriate care. There is a need to develop locally adapted behaviour change communication interventions for childhood Illnesses.

Keywords: health facilities; health seeking behaviour; urban slum; under-five children

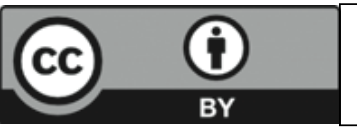

This work is licensed under creative common attribution 3.0 license 


\section{INTRODUCTION}

Children are the most vulnerable population across the globe and under-five mortality rate (U5MR) being an important indicator for the progress of any country. ${ }^{1}$ Declining of mortality in children under five years of age by over $50 \%$ in the last 25 years is the greatest achievement across the world. ${ }^{2}$ Despite the progress, millions of children suffer from illnesses which could be easily prevented by affordable simple interventions. ${ }^{1}$ However, U5MR in India is still higher than the targeted Sustainable Development Goal of 25 deaths per 1000 births in $2030 .^{3}$ In a developing country like India, the common cause of illness and death are infectious diseases. ${ }^{2}$ However, without appropriate treatment and lack of accessibility to health facility, under five children (U5C) continue to die. ${ }^{4}$ The unavailability of health facilities is not the only barrier but lack of motivation and inability of individuals to seek medical care are also major barriers. $^{5}$

Parents usually decide about the type and frequency of healthcare service accessed, so seeking healthcare in children is dependent on caregiver's knowledge and attitude. Moreover, a mother's health care seeking behaviour (HCSB) for their sick children is influenced by a varying number of socio- cultural factors. ${ }^{6}$

In Odisha, U5C deaths were reduced from 91 per 1000 live births in 2005 - 2006 to 45 per 1000 live births in 2015 - 2016 (NFHS). ${ }^{7}$ More importantly, this unmet need to access to health was higher amongst poorer sections. ${ }^{8}$ Under the National Health Mission free care in public hospitals are given, ${ }^{9}$ but the availability of staff, equipment and drugs varies significantly. It forces patients to seek care in the more expensive private sector. Because of these catastrophic health care costs, more than 63 million Indians are faced with impoverishment every year. ${ }^{10}$

The health indicators in slum populations are poorer than urban averages ${ }^{11,12}$ or similar or even worse than those of rural populations. So the risk of infectious diseases, malnutrition and possibly impaired cognitive development are more in the children of urban slums. ${ }^{13}$ The overall child morbidity and mortality rates are many times higher in slums than in more privileged urban neighbourhoods. ${ }^{12}$ An effort was made to assess the HCSB for their children, among caregivers of under-fives in urban slums of Bhubaneswar city.

\section{METHODS}

This study was a community-based cross-sectional study conducted in slums of Bhubaneswar city of Odisha, India from January 2019 to April 2019. The caregivers, whose children under five years of age were suffering from illnesses in last one month, were interviewed with prior consent. Approval by the institutional ethics committee was taken. Total 530 caregivers of U5 children, participated in the study. They were interviewed using a pre-designed and pre-tested schedule based on the National Sample Survey Office (NSSO) health consumption schedule 25.0, adapted to the study and contextualised to the local situation. The data collection was done in local language Odia. A recall period of one month was used to avoid any recall bias. The sample size for the study was calculated as 530. The samples were collected using multistage cluster sampling technique. The data were entered by using Epi Collection 5. The data were coded, cleaned, and extracted in .csv format and exported to $\mathrm{R}$ software version 3.1.1, using packages like "Epicalc", "epitools", "gmodels" etc. Then statistical analysis was done using univariate and bivariate analysis (chi-squared test). ${ }^{14}$

\section{Operational Definitions:}

- Caregiver: Caregivers were family members, in our case mother who were primarily responsible for supervising their child's health

- Healthcare-seeking behaviour (HCSB): Any activity undertaken by the caregivers who perceived their children to have a health problem and reached health care facility for the purpose of finding a remedy. This was based on the recognition of symptoms, and how they were interpreted by individuals

\section{RESULTS}

Among the 530 respondents, the mean age of their children was $3 \pm 1$ year. $51.1 \%$ children were males and $48.9 \%$ children were females. The mean age of 
Table 1. Socio-demographic characteristics of participants and nature of treatment

\begin{tabular}{|c|c|c|}
\hline \multirow{2}{*}{$\begin{array}{l}\text { Variables } \\
\text { Age of child } \\
\text { (Completed in years) }\end{array}$} & & \multirow{2}{*}{$\begin{array}{r}\text { Number (\%) } \\
29(5.5)\end{array}$} \\
\hline & 1 & \\
\hline & 2 & 85 (16) \\
\hline & 3 & $270(50.9)$ \\
\hline & 4 & $121(22.8)$ \\
\hline & 5 & $25(4.7)$ \\
\hline \multirow[t]{2}{*}{ Sex of Child } & Male & $271(51.1)$ \\
\hline & Female & $259(48.9)$ \\
\hline \multirow[t]{3}{*}{$\begin{array}{l}\text { Health care sought } \\
\text { type }\end{array}$} & $\begin{array}{l}\text { Visited only } \\
\text { OPD/Clinics }\end{array}$ & $276(52.2)$ \\
\hline & Admitted in IPD & $146(27.5)$ \\
\hline & $\begin{array}{l}\text { Not visited any } \\
\text { health facility }\end{array}$ & $107(20.2)$ \\
\hline \multirow{6}{*}{$\begin{array}{l}\text { Nature of ailment in } \\
\text { U5C }\end{array}$} & Diarrheal disease & $161(30.4)$ \\
\hline & $\begin{array}{l}\text { Respiratory } \\
\text { infection }\end{array}$ & $154(29.1)$ \\
\hline & Malaria & $75(14.2)$ \\
\hline & $\begin{array}{l}\text { Wound and skin } \\
\text { diseases }\end{array}$ & $94(17.7)$ \\
\hline & Measles & $3(0.6)$ \\
\hline & Other illness & $43(8.1)$ \\
\hline \multirow{4}{*}{$\begin{array}{l}\text { No. of times visited } \\
\text { OPD }\end{array}$} & 0 & $108(20.4)$ \\
\hline & 1 & $363(68.5)$ \\
\hline & 2 & $54(10.2)$ \\
\hline & 3 & $5(0.9)$ \\
\hline \multirow{2}{*}{$\begin{array}{l}\text { Suffering from any } \\
\text { chronic ailment }\end{array}$} & Yes & $44(8.3)$ \\
\hline & No & $486(91.7)$ \\
\hline \multirow{2}{*}{$\begin{array}{l}\text { Hospitalized in last } \\
30 \text { days }\end{array}$} & Yes & $146(27.5)$ \\
\hline & No & $384(72.5)$ \\
\hline \multirow{2}{*}{$\begin{array}{l}\text { Number of times } \\
\text { hospitalizedin last } 30 \\
\text { days }(n=146)\end{array}$} & 1 & $144(98.6)$ \\
\hline & 2 & $2(1.4)$ \\
\hline \multirow{3}{*}{$\begin{array}{l}\text { Type of ward (IPD) } \\
\text { admitted }(n=146)\end{array}$} & Free & $93(63.7)$ \\
\hline & $\begin{array}{l}\text { General ward on } \\
\text { payment }\end{array}$ & $52(35.6)$ \\
\hline & $\begin{array}{l}\text { Special ward on } \\
\text { payment }\end{array}$ & $1(0.7)$ \\
\hline
\end{tabular}

the mothers was $24.9 \pm 1.4$ years. Among them only $29 \%$ of families were having a regular wage occupation. The mean monthly expenditure of houses was INR 6345.1 $\pm 1569.2(\$ 84.67 \pm 20.94)$. The most common childhood illness in last one month preceding the date of interview was diarrhoeal disease (30.4\%) followed by respiratory infection (29.1\%). Other detailed background
Table 2. Pattern of health care sought

\begin{tabular}{|c|c|c|}
\hline \multicolumn{2}{|l|}{ Variables } & \multirow{2}{*}{$\begin{array}{l}\begin{array}{l}\text { Number } \\
(\%)\end{array} \\
235(44.3)\end{array}$} \\
\hline Level of care & Government & \\
\hline & Private & $192(36.2)$ \\
\hline \multirow{7}{*}{$\begin{array}{l}\text { Reason for taking } \\
\text { previous } \\
\text { treatment }\end{array}$} & $\begin{array}{l}\text { Previously } \\
\text { treated \& cured }\end{array}$ & $153(28.9)$ \\
\hline & $\begin{array}{l}\text { Near to house/ } \\
\text { easy accessibility }\end{array}$ & $113(21.3)$ \\
\hline & $\begin{array}{l}\text { Advice by family } \\
\text { member/ friends }\end{array}$ & $53(10)$ \\
\hline & $\begin{array}{l}\text { Cooperative } \\
\text { behavior of } \\
\text { doctors }\end{array}$ & $88(16.6)$ \\
\hline & Referred & $10(1.9)$ \\
\hline & for investigation & $1(0.2)$ \\
\hline & $\begin{array}{l}\text { Economic } \\
\text { reasons }\end{array}$ & $38(7.2)$ \\
\hline \multirow[t]{2}{*}{ Surgery done } & Yes & $41(7.7)$ \\
\hline & No & $479(90.4)$ \\
\hline \multirow[t]{2}{*}{ Medicine taken } & Yes & $473(89.2)$ \\
\hline & No & $49(9.2)$ \\
\hline \multirow{2}{*}{$\begin{array}{l}\text { Diagnostic tests } \\
\text { done }\end{array}$} & Yes & $291(54.9)$ \\
\hline & No & $225(42.5)$ \\
\hline \multirow{2}{*}{$\begin{array}{l}\text { Treated on } \\
\text { medical advice }\end{array}$} & Yes & $422(79.6)$ \\
\hline & No & $97(18.3)$ \\
\hline \multirow{2}{*}{$\begin{array}{l}\text { Treatment on } \\
\text { medical advice } \\
\text { continued after } \\
\text { discharge from } \\
\text { hospital }\end{array}$} & Yes & $160(30.2)$ \\
\hline & No & $75(14.2)$ \\
\hline
\end{tabular}

characteristics of illness and nature of treatment are explained in table 1.

$73.6 \%$ had Government insurance scheme for health expenditure, $3.8 \%$ had some other scheme for health insurance and $22.6 \%$ of the caregiver family didn't have any coverage for the health insurance scheme. Those benefiting medical services free of cost were only by $16.4 \%$ whereas $33.2 \%$ children received partly free treatment and a large proportion of children (34.2\%) availed 


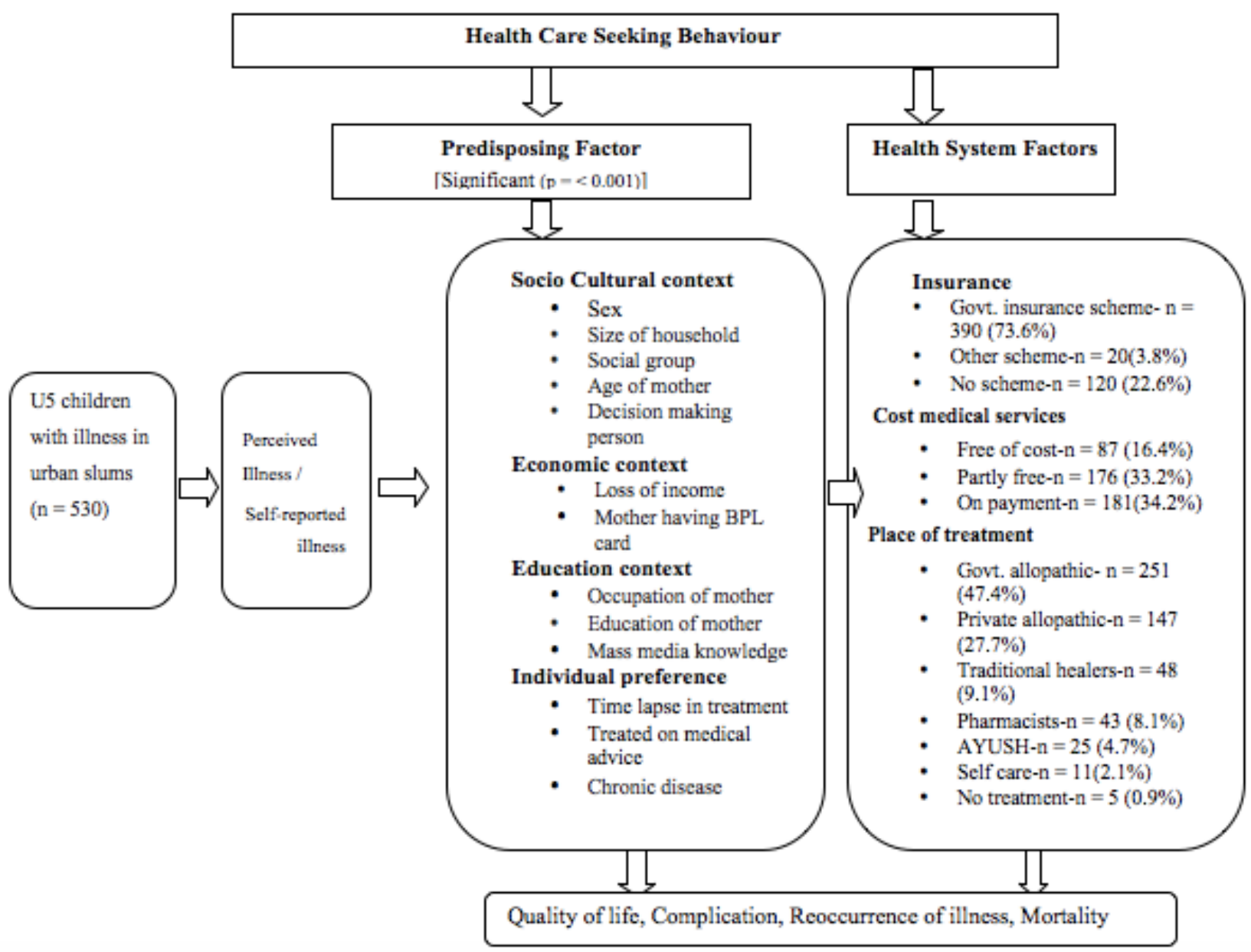

Figure 1. Concept analysis of HCSB among caregiver of U5 Children

treatment on payment. The pattern of health care service sought is described in table 2 .

The health care seeking approach was such that the majority of caregivers (47.4\%) of U5 children consulted a government allopathic doctor, whereas $27.7 \%$ consulted a private allopathic doctor, $9.1 \%$ consulted to traditional healers and $8.1 \%$ consulted to pharmacists. Similarly $4.7 \%$ consulted to ayurveda, unani or siddha, homoeopathy, yoga and naturopathy (AYUSH), 2.1\% adopted home remedies or consulted family friend advice and $0.9 \%$ did not seek any treatment.

The association of HCSB of caregiver was analysed using Chi Squared test. The health care sought was taken as the outcome variable and its association with the exposure variable was checked. The association is depicted in (Figure 1) as a concept analysis of HCSB where all predisposing factors are themed as "socio cultural context", "economic context", "education context", and "individual preference" to know the health care seeking pattern.

In socio cultural context "sex of child" $(\mathrm{P}=0.001)$ significantly contributed to HCSB. Moreover on comparison, caregiver's attitude for U5C illnesses among male and female child remarkably varied. Male children visited OPD and IPD (65.20\%-OPD, $51.40 \%$-IPD) more frequently as compared to female (34.80\%-OPD, 48.60\%-IPD). 85\% percent of female children did not visit OPD or IPD during illness, whereas $15 \%$ male children did not visit health care. Other variables significantly associated were "size of the household" $(p=0.001)$ "social group" of caregiver $(\mathrm{P}=0.001)$, "age of mother" ( $\mathrm{p}$ $=0.001)$, "decision making person" while seeking health care $(p=0.001)$. In economic context variables significantly related were "loss of 
Table 3. Factors associated with health care seeking behaviour of caregivers

\begin{tabular}{|c|c|c|c|c|}
\hline Variables & Visited OPD & Visited IPD & $\begin{array}{c}\text { Not visited OPD / } \\
\text { IPD }\end{array}$ & p-value \\
\hline \multicolumn{5}{|l|}{ Sex of child } \\
\hline Male & $65.20 \%$ & $51.40 \%$ & $15.00 \%$ & 0.00 \\
\hline Female & $34.80 \%$ & $48.60 \%$ & $85.00 \%$ & \\
\hline \multicolumn{5}{|l|}{ Household size } \\
\hline 0 to 4 members & $35.90 \%$ & $56.20 \%$ & $34.60 \%$ & 0.00 \\
\hline Above5 members & $64.10 \%$ & $43.80 \%$ & $65.40 \%$ & \\
\hline \multicolumn{5}{|l|}{ Religion of care giver } \\
\hline Hindu & $94.20 \%$ & $90.40 \%$ & $93.50 \%$ & 0.341 \\
\hline Others & $5.80 \%$ & $9.60 \%$ & $6.50 \%$ & \\
\hline \multicolumn{5}{|l|}{ Social group of care giver } \\
\hline SC \& ST & $59.10 \%$ & $41.10 \%$ & $46.70 \%$ & 0.001 \\
\hline Others & $40.90 \%$ & $58.90 \%$ & $53.30 \%$ & \\
\hline \multicolumn{5}{|l|}{ Mother with mass media knowledge } \\
\hline without mass media exposure & $2.90 \%$ & $16.40 \%$ & $80.40 \%$ & 0.00 \\
\hline with mass media exposure & $97.10 \%$ & $83.60 \%$ & $19.60 \%$ & \\
\hline \multicolumn{5}{|l|}{ Age of mother } \\
\hline 25 years and Below & $84.40 \%$ & $30.10 \%$ & $72.90 \%$ & 0.00 \\
\hline Above 25 years & $15.60 \%$ & $69.90 \%$ & $27.10 \%$ & \\
\hline \multicolumn{5}{|l|}{ Literacy status of mother } \\
\hline Illiterate & $3.60 \%$ & $19.20 \%$ & $70.10 \%$ & 0.00 \\
\hline Literate & $96.40 \%$ & $80.80 \%$ & $29.90 \%$ & \\
\hline \multicolumn{5}{|l|}{ Occupation of mother } \\
\hline Employed & $1.80 \%$ & $20.50 \%$ & $11.20 \%$ & 0.00 \\
\hline Non-employed & $98.20 \%$ & $79.50 \%$ & $88.80 \%$ & \\
\hline \multicolumn{5}{|l|}{ Type of family } \\
\hline Nuclear & $35.90 \%$ & $65.80 \%$ & $34.60 \%$ & 0.00 \\
\hline Joint family & $64.10 \%$ & $34.20 \%$ & $65.40 \%$ & \\
\hline \multicolumn{5}{|l|}{ Mother having BPL card } \\
\hline No & $2.20 \%$ & $13.00 \%$ & $89.70 \%$ & 0.00 \\
\hline Yes & $97.80 \%$ & $87.00 \%$ & $10.30 \%$ & \\
\hline \multicolumn{5}{|l|}{ Duration of stay in slum } \\
\hline Less than 6 years & $1.40 \%$ & $26.20 \%$ & $24.30 \%$ & 0.00 \\
\hline 7 years and above & $98.60 \%$ & $73.80 \%$ & $75.70 \%$ & \\
\hline \multicolumn{5}{|l|}{ Whether suffering from chronic disease } \\
\hline No & $98.60 \%$ & $74.00 \%$ & $98.10 \%$ & 0.00 \\
\hline Yes & $1.40 \%$ & $26.00 \%$ & $1.90 \%$ & \\
\hline \multicolumn{5}{|l|}{ Healthcare type } \\
\hline Govt. Health care & $51.70 \%$ & $61.00 \%$ & $58.30 \%$ & 0.187 \\
\hline Private Health care & $48.30 \%$ & $39.00 \%$ & $41.70 \%$ & \\
\hline \multicolumn{5}{|c|}{ Decision making person while seeking health care } \\
\hline Mother & $1.90 \%$ & $6.60 \%$ & $22.20 \%$ & 0.00 \\
\hline Others & $98.10 \%$ & $93.40 \%$ & $77.80 \%$ & \\
\hline \multicolumn{5}{|l|}{ Medicine take on advice } \\
\hline No & $3.60 \%$ & $0.00 \%$ & $39.40 \%$ & 0.00 \\
\hline Yes & $96.40 \%$ & $100.00 \%$ & $60.60 \%$ & \\
\hline \multicolumn{5}{|l|}{ Diagnostic test conducted } \\
\hline No & $35.40 \%$ & $23.90 \%$ & $93.90 \%$ & 0.00 \\
\hline Yes & $64.60 \%$ & $76.10 \%$ & $6.10 \%$ & \\
\hline Whether treated on medical advice & & & & \\
\hline No & $2.90 \%$ & $0.00 \%$ & $90.70 \%$ & 0.00 \\
\hline Yes & $97.10 \%$ & $100.00 \%$ & $9.30 \%$ & \\
\hline Whether continued treatment after $\mathrm{r}$ & & & & \\
\hline No & $19.40 \%$ & $30.10 \%$ & $100.00 \%$ & 0.00 \\
\hline Yes & $80.60 \%$ & $69.90 \%$ & $0.00 \%$ & \\
\hline Time lapse in approaching the healtl & & & & \\
\hline Immediately & $45.40 \%$ & $15.80 \%$ & $2.90 \%$ & 0.00 \\
\hline 2 days above & $54.60 \%$ & $84.20 \%$ & $97.10 \%$ & \\
\hline Loss of wage due to U5C ailment & & & & \\
\hline No wage loss & $39.30 \%$ & $0.00 \%$ & $82.10 \%$ & 0.00 \\
\hline Wage loss & $60.70 \%$ & $100.00 \%$ & $17.90 \%$ & \\
\hline
\end{tabular}


household income" due to absent from work for treatment of U5C ailment $(p=0.001)$ and status of "mother having BPL card" $(p=0.001)$. In education context "education of the mother" $(p=$ $0.001)$, "occupation of the mother" $(p=0.001)$, Mother with "mass media knowledge" $(p=0.001)$ were connected to influence HCSB. In individual preference "time lapse in approaching the source from where treatment was taken" ( $\mathrm{p}=$ $0.001)$, "whether treated on medical advice" ( $\mathrm{p}=$ $0.001)$, "whether treated on medical advice continued after hospitalisation" $(p=0.001)$ and "whether suffering from chronic disease" $(\mathrm{p}=$ 0.001 ) linked to HCSB. The relationship between care givers predisposing factors and health care seeking status of respondent as mentioned in the table-3.

\section{DISCUSSION}

This study highlighted on the aspect of HCSB of the caregivers towards childhood illnesses in the urban slum of Bhubaneswar, India. The mean age of the caregiver was about $24.9 \pm 1.4$ years. Around $21.5 \%$ of them were illiterate and $91.1 \%$ were unemployed. Similar findings have also been observed in studies in respect of unemployment. ${ }^{15,16}$ In a previous study conducted at Bhubaneswar, $77.69 \%$ were unemployed ${ }^{2}$ and in Tamil Nadu $76.54 \%$ were unemployed ${ }^{17}$ which was much less as compared to this study. In this study $30 \%$ of the under-five children had diarrhoeal disease which is approximately at par with that of earlier findings at Debrebirehan referral hospital $(31.7 \%)^{12}$ and at a health centres in Ethiopia $(30 \%){ }^{1}$

In this study as regards to the place of preference for seeking care, $47.4 \%$ consulted a "government allopathic doctor", $27.7 \%$ consulted an "allopathic private doctor", $4.7 \%$ consulted to "Ayurveda, Unani or Siddha, Homoeopathy, Yoga and Naturopathy" (AYUSH), 9.1\% consulted to "desi dawai or traditional healers", $8.1 \%$ consulted to "pharmacists", 2.1\% had "self-care" (home remedies or family friend advice) and only $0.9 \%$ had "no treatment." In another study, treatment was opted in government hospital (30.59\%) followed by medicine store, private clinics, anganwadi centres and quacks $(2.28 \%){ }^{2}$ Similarly in a study at urban slum of Lucknow, India, the respondents primarily preferred qualified private practitioner $(65.4 \%)$, followed by unqualified private practitioner $(26.9 \%)$ and tertiary care health centre $(7.8 \%) .{ }^{15}$ However in another study in Tamil Nadu reported around $81.15 \%$ of the caregivers preferred private doctors during any childhood illness and as few as $18.85 \%$ preferred a government health centre. ${ }^{18}$ This difference in utilisation of healthcare facility may be because of the difference in accessibility and quality of the health care delivered in those regions.

In this study, decision-making person for seeking health care were mostly fathers $(26 \%)$. It was seen in a study that the decision making abilities of the mothers mostly influence the HCSB. ${ }^{19}$ However, the concept analysis of this study clearly indicates the following HCSB aspects of the caregivers, which are broadly grouped under: "economic context", "Socio cultural context","education context", "individual preference." Concept analysis have been done in another study discussing the antecedents of concept for HCSB. ${ }^{20}$

As regards to "economic context" influencing HCSB of caregivers are "loss of household income", "mother having BPL card", "Socio cultural context" covers factors like "sex of child", "size of the household","social group", "age of mother" and "decision making person" etc. One study clearly describes how these socio-economic factors are acting as barriers to access health care. ${ }^{21,22}$ However in our study it has been observed that the sex of child plays a very important role in HCSB of caregiver. As has been observed, male as compared to female child had more often visited OPD and IPD. It was surprising that $85 \%$ percent of female didn't visit either OPD or IPD during illness. However in another study $30 \%$ of the female children, received no treatment which was much lower as compared to our study. ${ }^{23}$ Multiple studies show that various factors, such as age and sex of the children, wealth index, the education of the mother, access to electronic media and household lifestyle factors were significantly associated with care-seeking behaviours. ${ }^{24,25}$

As regards to "education context" the factors affecting to HCSB of caregivers are like "mother education", "occupation of the mother", mother with "mass media knowledge." In this respect 
another study revealed similar findings, where the caregivers with secondary school education were four times more likely to seek healthcare than noneducated ones. ${ }^{1}$ Mother's education is associated with good hygiene and HCSBs resulting in decrease in childhood illness. The "individual preference" influencing HCSB of caregivers are "time lapse in approaching the source from where treatment was taken", "whether treated on medical advice" etc. Similar findings have also been observed in another study. ${ }^{26}$ Although our research has tried to dwell upon the various factors associated with health care seeking behaviour of caregivers, it is a cross-sectional study using a selfadministered questionnaire and pattern of HCSB over time could not be assessed. Chance of recall bias leading to variation of results was a possibility, even though illness within last one month was considered. These facts would limit us to generalise our findings to the entire general population. We expect that further larger, more comprehensive, prospective studies in the future would shed more light upon this subject.

\section{CONCLUSIONS}

This study highlights the HCSB of caregivers of under-five children in urban slums. This study recognises socio cultural determinants like sex of child, size of the household, social group of caregiver, mother with mass media knowledge, age of mother, education of the mother, occupation of the mother, decision making person for seeking health care, delay in approaching for treatment and wage loss were associated with health care seeking behaviour for their under-five children illnesses. The challenge is to know about signs and symptoms of ill-health and to recognise when to seek health care services. Measures can be taken to promote awareness for seeking timely appropriate care. There is a need to develop locally adapted behaviour change communication interventions for childhood Illnesses.

\section{REFERENCES}

1. Abegaz NT, Berhe H, Gebretekle GB. Mothers/caregivers healthcare seeking behavior towards childhood illness in selected health centers in Addis Ababa, Ethiopia: a facility-based cross-sectional study. BMC Pediatr. 2019 Jul 3;19(1):220. DOI:https://doi.org/10.1186/s12887-019-1588-2

2. Mishra K, Mohapatra I, Kumar A. A study on the health seeking behavior among caregivers of under-five children in an urban slum of Bhubaneswar, Odisha. J Fam Med Prim Care. 2019 Feb;8(2):498-503. DOI:https://doi.org/ 10.4103/jfmpc.jfmpc_437_18.

3. McIntyre D, Ranson MK, Aulakh BK, Honda A. Promoting universal financial protection: evidence from seven low- and middle-income countries on factors facilitating or hindering progress. Health Res Policy Syst. 2013 Sep 24;11:36. DOI: https://doi.org/10.1186/1478-4505-11-36 .

4. Deshmukh V, Lahariya C, Krishnamurthy S, Das MK, Pandey RM, Arora NK. Taken to Health Care Provider or Not, Under-Five Children Die of Preventable Causes: Findings from Cross-Sectional Survey and Social Autopsy in Rural India. Indian J Community Med Off Publ Indian Assoc Prev Soc Med. 2016;41(2):108-19. DOI: https:// doi.org/10.4103/0970-0218.177527 .

5. Mane V, Sagar M. Morbidity profile of Preschool children in a rural community of Shimoga, Karnataka. Indian J Forensic Community Med. 2018 Oct 30;5(3):164-7. DOI:https://doi.org/10.18231/2394-6776.2018.0037 .

6. Mbagaya GM, Odhiambo MO, Oniang'o RK. Mother's health seeking behaviour during child illness in a rural western Kenya community. Afr Health Sci. 2005 Dec;5(4):322-7. PMID: 16615844.

7. Bora JK, Saikia N. Neonatal and under-five mortality rate in Indian districts with reference to Sustainable Development Goal 3: An analysis of the National Family Health Survey of India (NFHS), 2015-2016. PLoS ONE. 2018 Jul 30;13(7). DOI:https://doi.org/10.1371/journal.pone.0201125

8. Ottersen T, Norheim OF. World Health Organisation Consultative Group on Equity and Universal Health Coverage. Making fair choices on the path to universal health coverage. Bull World Health Organ. 2014 Jun 1;92(6):389. DOI:https://doi.org/10.2471/blt.14.139139 . 
9. Lakshminarayanan S. Role of government in public health: Current scenario in India and future scope. J Fam Community Med. 2011;18(1):26-30. DOI:https://doi.org/10.4103/1319-1683.78635 .

10. Hadaye RS, Thampi JG. Catastrophic Health-care Expenditure and Willingness to Pay for Health Insurance in a Metropolitan City: A Cross-Sectional Study. Indian J Community Med Off Publ Indian Assoc Prev Soc Med. 2018;43(4):307-11. DOI: 10.4103/ijcm.IJCM_252_18.

11. Mishra S, Kusuma YS, Babu BV. Mother's Recognition of and Treatment Triggers for Common Childhood Illnesses among Migrant Santal Tribe Living in Bhubaneswar, Odisha, India. J Trop Pediatr. 2017 Aug 1;63(4):3016. DOI: https://doi.org/10.1093/tropej/fmw092 .

12. Nair D, Kar SS, Selvaraj K, Ramalingam A. Morbidity profile and out of pocket health care expenditure among under five children of an urban area of Puducherry. J Nat Sci Biol Med. 2015 Aug;6(1):139-42. DOI: https://doi.org/ $10.4103 / 0976-9668.166122$.

13. Mishra S, Kusuma YS, Babu BV. Treatment-seeking and out-of-pocket expenditure on childhood illness in a migrant tribal community in Bhubaneswar, Odisha State, India. Paediatr Int Child Health. 2017 Jul 3;37(3):181-7. DOI: $10.1080 / 20469047.2016 .1245031$.

14. R: The R Project for Statistical Computing. [cited 2019 Apr 14]. Available from: https://www.r-project.org/

15. Minz A, Agarwal M, Singh JV, Singh VK. Care seeking for childhood pneumonia by rural and poor urban communities in Lucknow: A community-based cross-sectional study. J Fam Med Prim Care. 2017;6(2):211-7. DOI: 10.4103/2249-4863.219987.

16. Tahsina T, Ali NB, Hoque DME, Huda TM, Salam SS, Hasan MM, et al. Out-of-pocket expenditure for seeking health care for sick children younger than 5 years of age in Bangladesh: findings from cross-sectional surveys, 2009 and 2012. J Health Popul Nutr. 2017;36. DOI: https://doi.org/10.1186/s41043-017-0110-4

17. Kolola T, Gezahegn T, Addisie M. Health Care Seeking Behavior for Common Childhood Illnesses in Jeldu District, Oromia Regional State, Ethiopia. PLoS ONE. 2016 Oct 14;11(10):1-5. DOI:https://doi.org/10.1371/ journal.pone. 0164534

18. Annadurai K, Venkatesh S, Ramaswamy J. Health-seeking behaviour on child care among fisherman community of Kovalam village, Tamil Nadu, India. Online J Health Allied Sci. 2015;14:5. DOI:https://doi.org/ 10.18203/2394-6040.ijcmph20180255

19. Chintaman Patil S, Dixit P. Health Seeking Behaviour among 0-5 Years of Children in Diarrhea in Rural Wardha District, Maharashtra. Prim Health Care Open Access. 2018;08(02). DOI: https://doi.org/ 10.4172/2167-1079.1000299

20. Poortaghi S, Raiesifar A, Bozorgzad P, Golzari SEJ, Parvizy S, Rafii F. Evolutionary concept analysis of health seeking behavior in nursing: a systematic review. BMC Health Serv Res. 2015 Nov 27;15. DOI: https://doi.org/ 10.1186/s12913-015-1181-9

21. Chibwana AI, Mathanga DP, Chinkhumba J, Campbell CH. Socio-cultural predictors of health-seeking behaviour for febrile under-five children in Mwanza-Neno district, Malawi. Malar J. 2009 Sep 24;8(1):219. DOI: https:// doi.org/10.1186/1475-2875-8-219

22. Wambui WM, Kimani S, Odhiambo E. Determinants of Health Seeking Behavior among Caregivers of Infants Admitted with Acute Childhood Illnesses at Kenyatta National Hospital, Nairobi, Kenya. Int J Pediatr. 2018 Dec 16;2018. DOI: https://doi.org/10.1155/2018/5190287

23. Yerpude PN, Jogdand KS, Shah JH, Thacker KB. A study of factors which determine health seeking behavior of mothers for their under five children in rural area of Gujarat. Int J Community Med Public Health. 2017 Oct 25;4(11):4169-73. DOI: https://doi.org/10.18203/2394-6040.ijcmph20174822 .

24. Sarker AR, Sultana M, Mahumud RA, Sheikh N, Van Der Meer R, Morton A. Prevalence and Health Care-Seeking Behavior for Childhood Diarrheal Disease in Bangladesh. Glob Pediatr Health. 2016 Jan 1;3:2333794X16680901 DOI: https://doi.org/10.1177/2333794x16680901 .

25. Sultana M, Sarker AR, Sheikh N, Akram R, Ali N, Mahumud RA, et al. Prevalence, determinants and health careseeking behavior of childhood acute respiratory tract infections in Bangladesh. PLOS ONE. 2019 Jan 10;14(1):e0210433. DOI: https://doi.org/10.1371/journal.pone.0210433

26. Laskar AR, Gupta V, Singh M, Kumar D, Ingle G. Treatment Seeking Pattern Among Parents of Children with Locomotor Disablity. Indian J Community Med Off Publ Indian Assoc Prev Soc Med. 2009 Jul;34(3):258-60. DOI: https://doi.org/10.4103/0970-0218.55297 